\title{
RECOMMENDATION OF NON-DESTRUCTIVE SAMPLING METHOD FOR DENSITY ESTIMATION OF THE Eucalyptus WOOD
}

\author{
Franciane Andrade de Pádua ${ }^{1, \AA}$, João Otávio Poletto Tomeleri ${ }^{1}$, Mariana Pires Franco ${ }^{3}$, \\ José Reinaldo Moreira da Silva ${ }^{2}$, Paulo Fernando Trugilho ${ }^{2}$
}

\begin{abstract}
This study aimed to determine the wood density using destructive and non-destructive sampling methods in a eucalypt hybrid clonal and determine the best point for the non-destructive sampling of the tree. A 5,6-year-old Eucalyptus urophylla x Eucalyptus grandis hybrid clone, from an energetic forest, was used, planted in the municipal district of Martinho Campos, MG, Brazil. The trees were sampled by three methods of destructive sampling. The traditional method ( $0 \%, 25 \%, 50 \%, 75 \%$ and $100 \%$ of the commercial height Hc); alternative method $(2 \%, 10 \%, 30 \%$ and $70 \% \mathrm{Hc})$ and via a meter by meter method starting from a height of $1,30 \mathrm{~m}$ from the soil (DBH). Three non-destructive sampling methods were also appraised: Resistograph ${ }^{\mathrm{N}}$, Pi-

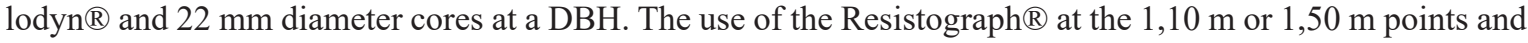
the Pilodyn ${ }^{\circledR}$ at $1,50 \mathrm{~m}$ of height from the soil results the best correlations with the basic density determined by the three destructive sampling methods considered.
\end{abstract}

Keywords: Basic density, eucalypts, pilodyn, resistograph, standing tree properties.

\section{INTRODUCTION}

The wood can be considered a heterogeneous natural polymer with a complex organization, consisting of lignin, cellulose, hemicelluloses, and extractives, that vary as much as the proportions found in several genera, species and even between individuals (Santos 2008).

To better interpret the characteristics produced by the chemical composition presented by the wood, is essential to consider the identification of the anatomical features as a description of the quality of the wood, such as vessel and fiber dimensions, heartwood ratio about the sapwood, the abundance of extractives, among others. More precisely, the characteristic that best represents the quality of the wood, and which has the highest capacity to summarize the properties of the wood is the basic density. The density is the result of the integration of the physical-chemical properties with the anatomical ones, being widely used to qualitatively characterize several wood products (Sette Jr 2012).

For the proper evaluation of the quality of the wood for any use, the identification of the properties that affect the final product is fundamental. In this sense, the basic density is considered an important qualitative index of the wood for its diverse uses. It is because the basicdensity is correlated with a high number of other properties and consequently exerts a high influence on the quality and yield of specific products, besides its importance in the estimation of forest biomass and carbon storage.It is also a property of easy determination and high heritability.

Wood is a heterogeneous and highly variable material. Its properties vary between trees and individually, in the longitudinal and radial directions of the stem. For this reason, sampling is one of the leading obstacles to achieving significant results, due to the high variability of the anatomical, physical, chemical and mechanical

\footnotetext{
${ }^{1}$ Department of Environmental Sciences, Federal University of São Carlos, João Leme dos Santos Highway, Sorocaba-SP, Brazil.

${ }^{2}$ Department of Forestry Sciences, Federal University of Lavras, Lavras-MG, Brazil.

${ }^{3}$ Department of Forestry Sciences, ESALQ - USP, Piracicaba-SP, Brazil.

•Corresponding author: franciane@ufscar.br

Received: 08.12.2017 Accepted: 03.08.2019
} 
characteristics that are verified between the trees, within each tree and also between different ages and sites (Zobel and van Buijtenen 1989). Therefore, knowledge of these variations for differentspecies is vital for a more accurate determination of wood density and biomass estimates (Wassenberg et al. 2015). Considering the significantvariation found for the density characteristic, it is essential that the sampling process be fast, efficient and always ensures a good representation of the whole, making it possible, with low experimental costs, to obtain accurate data on the basic density of the trees of interest.

The ideal for proper assessment of wood quality would be the removal of multiple samples at different tree heights and radial positions. However, this is not always possible because this type of sampling is more difficult, requires more time, and involvesthe slaughtering of the tree sampled (Downes et al. 1997). Therefore, the use of more straightforward methods that provide reasonable accuracy becomes necessary (Zobel and van Buijtenen 1989), since, in addition to the operational difficulties of destructive sampling, the number of trees sampled is limited.

In this sense, non-destructive methods are important tools for evaluating wood properties, since these techniques seek to qualify the material without compromising its future use. Also, the methods allow time and cost savings in sample preparation, as opposed to destructive sampling. However, the main disadvantage of non-destructive sampling is that it can only be used for the estimation of the properties of the tree when there is a high correlation between the positions sampled and the average value of the property of the whole tree.

The estimation of the wood density by non-destructive methods is performed using devices such as the Pilodyn ${ }^{\circledR}$, an apparatus that relates the resistance of the wood to the penetration of a pin in its outer parts to obtain data of density, used by Greaves et al. (1996), Raymond and MacDonald (1998), MacKenzie et al. (2003), the Resistograph ${ }^{\circledR}$, an apparatus that determines the strength of the wood in relation to the penetration of a metal drill through the whole diameter of the stem, used by Barría et al. (2017), Isik andLi (2003), Rinn et al. (1996) and Lima et al. (2007), and a motorized extractor for removal of a baguette, a linear sample of wood at the transverse direction of the tree, used by Downes et al. (1997) and Raymond and Muneri (2001).

In this context, the objectives of this work were to determine the basic wood density using destructive and non-destructive sampling methods in a clonal hybrid of Eucalyptus grandis x Eucalyptus urophylla. Moreover, also to stipulate an optimum sampling point for the non-destructive process, based on the best correlation between the sampled position and the basic density determined by three different methods of destructive sampling.

\section{MATERIALS AND METHODS}

The destructive and non-destructive sampling methodologies were applied in a total of 50 trees of a clonal hybrid of Eucalyptus urophylla ST Blake x Eucalyptus grandis W. Hill ex Maiden, with an average commercial height of 17,11 $\mathrm{m}$ at 5,6 years of age. The planting had a spacing configuration of $3 \times 2$ meters in an area belonging to the group Arcelor Mittal Bioenergia, in Martinho Campos, in the state of Minas Gerais, Brazil. The field selected for the study occupies an area of 44 hectares and is located at 19'39'20 "south and $45^{\circ} 19^{\prime} 30^{\prime \prime}$ west. Within this position, a plot with 10 rows x 10 plants was established, considered to be the population of this clone. The description of the different applied methodologies of sampling for basic density estimation is presented below.

\section{Destructive sampling}

\section{Traditional}

The "traditional sampling" method refers to the sampling procedure most commonly used to characterize wood properties in the longitudinal direction of the stem. For this, five discs of 2,5 cm thickness were removed from each stem in the base position and $25 \%, 50 \%, 75 \%$ and $100 \%$ of the commercial height of the tree, that is, up to the minimum diameter of $5 \mathrm{~cm}$ considering thebark.

\section{Alternative sampling}

The method called "alternative sampling" had the methodology of longitudinal sampling proposed by 
Downes et al. (1997) as the basis. It is used to verify the pattern of longitudinal variation of basic density and fiber morphology in different species of Eucalyptus, ages, and sites. Based on this work $2,5 \mathrm{~cm}$ thick discs were removed at relative heights of $2 \%, 10 \%, 30 \%, 50 \%$ and $70 \%$ of the commercial height of each tree. It is important to mention that in the work of Downes et al. (1997), these sampling positions were relative to the total height of the tree and not to the commercial height as is the case of this study.

\section{Sampling meter by meter}

The method called "measurement per meter of sampling" consists of removing 2,5 cm thick discs at fixed heights of the base $1,30 \mathrm{~m}$ in height and, from that point, one meter per meter to the commercial height. The number of longitudinal sampling points was limited to the commercial height of the tree.For the study of density variation with height, four points were added: $0,7 \mathrm{~m} ; 0,9 \mathrm{~m} ; 1,10 \mathrm{~m}$ and $1,50 \mathrm{~m}$ of soil height. This sampling was called "measurement per meter, with base points added." It was taken as a reference to be the most representative sample, especially at the base of the stem.

\section{Non-destructive sampling}

Three different types of equipment were used to perform the non-destructive sampling to infer the basic density of the stem. The motorized extractor, the Pilodyn ${ }^{\circ}$, and the Resistograph ${ }^{\circledR}$.

\section{Sampling with mechanized extractor}

From each sampled tree, a linear sample of $20 \mathrm{~mm}$ diameter, called a bagueta, was removed from the stem in the radial direction using a motorized extraction system. The samples were removed at $1,30 \mathrm{~m}$ from the soil.

\section{Sampling with pilodyn ${ }^{\circledR}$}

The Pilodyn ${ }^{\circledR}$ equipment was used to measure the mechanical strength of the wood at the penetration of a pin and thus predict the basic density. The readings were performed at heights of $0,70 \mathrm{~m} ; 0,90 \mathrm{~m} ; 1,10 \mathrm{~m} ; 1,30$ $\mathrm{m}$ and $1,50 \mathrm{~m}$ from the soil. These heights were recommended by Raymond andMuneri (2001) as the positions that presented the best correlations between non-destructive sampling results (Pilodyn ${ }^{\circledR}$ readings and cores) and the basic stem density of different species of eucalyptus. Four readings were taken at each sampled height, two in the direction of the planting line and two between lines, trying to obtain the average basic density in the circumference of the tree in the most basal positions.

\section{Sampling with resistograph ${ }^{\circledR}$}

The measurements were performed at the same longitudinal positions and directions considered for the Pilodyn ${ }^{\circledR}$, at heights at $0,70 \mathrm{~m} ; 0,90 \mathrm{~m} ; 1,10 \mathrm{~m} ; 1,30 \mathrm{~m}$ and $1,50 \mathrm{~m}$ from the ground. Two perforations were made at each height, in opposite directions of the stem.

\section{RESULTS AND DISCUSSION}

A comparison was made to indicate the best sampling point using the non-destructive methodology with the values collected along the height of the tree by the two devices, the Pilodyn, and the Resistor, to then get the correlation data between them.

Table 1 presents the correlation coefficient between the penetration depth of the Pilodyn pin and the amplitude generated by the Resistograph at different sampling points at the base of the trunk of the tree. 
Table 1: Correlation coefficients of the Pilodyn and Resistograph readings at five different basal sampling heights.

\begin{tabular}{|c|c|c|c|c|c|}
\hline \multicolumn{7}{|c|}{ Correlation coefficients } \\
\hline $\begin{array}{c}\text { Sampling } \\
\text { height }\end{array}$ & $\mathbf{0 , 7 0} \mathbf{~ m}$ & $\mathbf{0 , 9 0 ~} \mathbf{~}$ & $\mathbf{1 , 1 0} \mathbf{~ m}$ & $\mathbf{1 , 3 0} \mathbf{~ m}$ & $\mathbf{1 , 5 0} \mathbf{~ m}$ \\
\hline $0,70 \mathrm{~m}$ & $-0,16$ & $-0,21$ & -022 & $-0,30$ & $-0,25$ \\
\hline $0,90 \mathrm{~m}$ & $-0,21$ & $-0,33$ & $-0,22$ & $-0,27$ & $-0,30$ \\
\hline $1,10 \mathrm{~m}$ & $-0,38$ & $-0,43$ & $-0,41$ & $-0,48$ & $-0,49$ \\
\hline $1,30 \mathrm{~m}$ & $-0,45$ & $-0,51$ & $-0,50$ & $-0,54$ & $-0,54$ \\
\hline $1,50 \mathrm{~m}$ & $-0,35$ & $-0,50$ & $-0,48$ & $-0,47$ & $-0,57$ \\
\hline
\end{tabular}

The correlation coefficients between the readings provided by Pilodyn and Resistograph were negative and of low magnitude. In general, the highest correlations occurred at $1,30 \mathrm{~m}$ at soil height, a position traditionally considered for sampling and non-destructive assessments in the trunk. Considering the single sampling, the indicated point for the use of the two types of equipment was to $1,50 \mathrm{~m}$ of theheight of the ground $(-0,57)$.

The weak and moderate correlations presented in Table 1 are results of the different ways of obtaining the Pilodyn and Resistograph readings. The readings provided by the Pilodyn refer only to the external wood (the pine penetrates to a depth of $40 \mathrm{~mm}$ in the stem), while the Resistograph reads the entire radial extent of the trunk.

Table 2 shows the correlation coefficients obtained between the amplitude determined by Resistograph and the mean basic density, obtained in a destructive way, determined at different basal sampling points in the trunk.

Table 2: Correlation coefficients for the data obtained with the Resistograph and the basic density of the sampling points.

\begin{tabular}{|c|c|c|c|c|c|c|}
\hline \multirow{2}{*}{$\begin{array}{c}\text { Sampling } \\
\text { heights }\end{array}$} & \multicolumn{7}{|c|}{ Correlation coefficients } \\
\cline { 2 - 7 } & Base & $\mathbf{0 , 7 0 ~} \mathbf{~}$ & $\mathbf{0 , 9 0} \mathbf{~ m}$ & $\mathbf{1 , 1 0} \mathbf{~ m}$ & $\mathbf{1 , 3 0} \mathbf{~ m}$ & $\mathbf{1 , 5 0} \mathbf{~ m}$ \\
\hline $0,70 \mathbf{m}$ & 0,40 & 0,39 & 0,48 & 0,63 & 0,50 & 0,55 \\
\hline $0,90 \mathrm{~m}$ & 0,24 & 0,46 & 0,57 & 0,56 & 0,37 & 0,44 \\
\hline $1,10 \mathrm{~m}$ & 0,31 & 0,58 & 0,57 & 0,73 & 0,56 & 0,78 \\
\hline $1,30 \mathrm{~m}$ & 0,18 & 0,34 & 0,58 & 0,60 & 0,59 & 0,65 \\
\hline $1,50 \mathrm{~m}$ & 0,34 & 0,59 & 0,51 & 0,69 & 0,51 & 0,65 \\
\hline
\end{tabular}

High correlations were observed between mean trunk density and the Resistograph reading at $1,10 \mathrm{~m}$ $(0,73)$ and $1,50 \mathrm{~m}(0,78)$ height positions. It indicates that at such sampling points, the reading of the Resistograph best represents the average density of the wood.The data indicate that lower sampling points should also be avoidedfor the use of this equipment below $1,10 \mathrm{~m}$.

The sampling height of $1,30 \mathrm{~m}$ of soil height, a position traditionally used for the application of the apparatus, presented a moderate correlation with the basic density of the wood at this point $(0,59)$.

Table 3 shows the correlation data of the Resistograph amplitude values with the average density obtained by four sampling methodologies, being three destructive and one nondestructive (mechanized extractor).

Table 3: Correlation coefficients between the values of amplitude of the Resistograph obtained in five positions and the average density of the tree determined by the destructive sampling methods and the mechanized

extractor.

\begin{tabular}{|c|c|c|c|c|}
\hline \multirow{2}{*}{$\begin{array}{c}\text { Sampling } \\
\text { height }\end{array}$} & \multicolumn{4}{|c|}{ Correlation coefficients } \\
\cline { 2 - 5 } & Ext & Trad & Alter & M/M \\
\hline $0,70 \mathrm{~m}$ & 0,35 & 0,50 & 0,55 & 0,58 \\
\hline $0,90 \mathrm{~m}$ & 0,16 & 0,46 & 0,46 & 0,51 \\
\hline $1,10 \mathrm{~m}$ & 0,40 & 0,67 & 0,75 & 0,78 \\
\hline $1,30 \mathrm{~m}$ & 0,45 & 0,54 & 0,64 & 0,66 \\
\hline $1,50 \mathrm{~m}$ & 0,19 & 0,71 & 0,74 & 0,75 \\
\hline
\end{tabular}

Ext $=$ sample removed at $1,30 \mathrm{~m}$ of soil height (DAP) with the mechanized extractor. Trad, Alter and $\mathrm{M} / \mathrm{M}=$ traditional sampling methodology, alternative sampling methodology and sampling methodology of a meter by meter, respectively. 
The different destructive sampling methods resulted in different mean stem density values. In general, considering the three methods, high correlations between the Resistograph amplitude values and mean stem density were detected at $1,10 \mathrm{~m}$ and $1,50 \mathrm{~m}$ at soil height. Based on the mean tree density obtained by the most intensive sampling $(\mathrm{M} / \mathrm{M})$, the best correlation with the Resistograph amplitude is at the point of $1,10 \mathrm{~m}(0,78)$.

The basic density at whole tree was estimated at the highest accuracy using the resistograph in DAP as the only predictor variable in a simple linear regression model, highly significant, in Pinus radiata (Barría et al. 2017).

The correlations between the density obtained by the non-destructive method (mechanized extractor) and the amplitude of the Resistograph were weak, although the two methods estimate the density to the full diametral extent. Padua (2009) and Barrichelo et al. (1983) point to the fact that bagueta sampling underestimates the tree mean density. This fact may be associated with non-proportionality of the zones of highest and lowest density in the radial direction, especially in the region of the marrow, when considering the bagueta. Omonte andValenzuela (2011) note conflicting results between researches, caused by different sampling methodologies (core and discs) and different methods of determining wood density.

As in the correlation evaluations between the Resistograph, the data obtained from the comparison between the values determined with the Pilodyn apparatus and the density estimated at the five different points of sampling along the trunk were analyzed.

Table 4 presents the correlation data between the penetration values of the Pilodyn pin and the basic density of the tree at different basal sampling points.

Table 4: Correlation coefficient between the values of penetration of the Pilodyn and the basic density determined in different points of the tree.

\begin{tabular}{|c|c|c|c|c|c|c|}
\hline \multirow{2}{*}{$\begin{array}{c}\text { Sampling } \\
\text { height }\end{array}$} & \multicolumn{7}{|c|}{ Correlation coefficients } \\
\cline { 2 - 7 } & Base & $\mathbf{0 , 7 0} \mathbf{~ m}$ & $\mathbf{0 , 9 0} \mathbf{~ m}$ & $\mathbf{1 , 1 0} \mathbf{~ m}$ & $\mathbf{1 , 3 0} \mathbf{~ m}$ & $\mathbf{1 , 5 0} \mathbf{~ m}$ \\
\hline $0,70 \mathbf{m}$ & $-0,10$ & $-0,37$ & $-0,30$ & $-0,47$ & $-0,46$ & $-0,47$ \\
\hline $0,90 \mathrm{~m}$ & $-0,02$ & $-0,47$ & $-0,39$ & $-0,52$ & $-0,47$ & $-0,50$ \\
\hline $1,10 \mathrm{~m}$ & $-0,03$ & $-0,44$ & $-0,34$ & $-0,52$ & $-0,47$ & $-0,51$ \\
\hline $1,30 \mathrm{~m}$ & $-0,07$ & $-0,37$ & $-0,35$ & $-0,53$ & $-0,53$ & $-0,53$ \\
\hline $1,50 \mathrm{~m}$ & $-0,04$ & $-0,44$ & $-0,38$ & $-0,56$ & $-0,52$ & $-0,59$ \\
\hline
\end{tabular}

The correlations between the penetration resistance of the Pilodyn pin and the mean basic trunk density were negative and of low to moderate magnitude. The highest correlation between the basic density and the Pilodyn readings was detected at $1,50 \mathrm{~m}(-0,59)$, indicating that this is the best position for its use. Low and moderate correlations between the penetration of the Pilodyn pin and the basic density were also verified by Rosado et al. (1983) and Couto et al. (2013) in eucalypt wood.

As in the case of the Resistograph, the tendency to increase the correlation was observed as the sampling height increased as well, indicating that points close to the base should be avoided.

Several authors criticize the use of Pilodyn for obtaining information of the wood produced in the most peripheral region of the trunk. However, it is a fast and easy to usedevice that can be applied in conditions where the intention is to make a preliminary classification of a large population containing different genetic materials (Nunes et al. 2016, Fukatsu et al. 2011 and Wei and Borralho 1997).

Table 5 shows the correlation coefficients between the values obtained through Pilodyn and the mean density of the tree determined by the different destructive methods and the mechanized extractor, confirming the low efficiency of the Pilodyn application as an estimate of the average density. 
Table 5: Correlation coefficients between the values of penetration of the Pilodyn obtained in five points and the average density of the tree determined by the destructive sampling methods.

\begin{tabular}{|c|c|c|c|c|}
\hline \multirow{2}{*}{$\begin{array}{c}\text { Sampling } \\
\text { height }\end{array}$} & \multicolumn{4}{|c|}{ Correlation coefficients } \\
\cline { 2 - 5 } & Ext & Trad & Alter & M/M \\
\hline $0,70 \mathrm{~m}$ & $-0,28$ & $-0,49$ & $-0,43$ & $-0,56$ \\
\hline $0,90 \mathrm{~m}$ & $-0,27$ & $-0,57$ & $-0,48$ & $-0,60$ \\
\hline $1,10 \mathrm{~m}$ & $-0,31$ & $-0,50$ & $-0,46$ & $-0,56$ \\
\hline $1,30 \mathrm{~m}$ & $-0,39$ & $-0,51$ & $-0,50$ & $-0,58$ \\
\hline $1,50 \mathrm{~m}$ & $-0,31$ & $-0,57$ & $-0,53$ & $-0,64$ \\
\hline
\end{tabular}

Ext $=$ mechanized extractor, with sample removed at 1,30 $\mathrm{m}(\mathrm{DBH})$. Trad, Alter and $\mathrm{M} / \mathrm{M}=$ traditional, alternative and sampling meter by meter, respectively.

The values of the correlation between the Pilodyn readings and the basic trunk density can be considered from low to moderate magnitude, regardless of the sampling method considered.

Analyzing the sampling points about the destructive sampling methods, the penetration of the Pilodyn pin obtained at the height of $1,50 \mathrm{~m}$ from the soil showed a correlation of greater magnitude.

Comparing with the methodology of sampling of meter by meter, the best results appeared from a height of $1,30 \mathrm{~m}$ of the ground $(-0,64)$, a similar result to the one verified by the Resistograph. Gouvêa et al. (2011), found data that showed that the Resistograph had a higher coefficient of determination (74\%), whereas Pilodyn presented only $57 \%$, which indicates that the Resistograph, in general, is the most appropriate device for estimating density.

Table 6 presents the correlation values between the estimated density at the different sampling points and the mean density values obtained by the destructive sampling methods.

Table 6: Correlation between the estimated basic density at different sampling points and the values obtained by the destructive sampling methods.

\begin{tabular}{|c|c|c|c|c|c|c|c|c|c|c|}
\hline \multicolumn{10}{|c|}{ Correlation coefficient } \\
\hline & Base & $\mathbf{0 , 7 0} \mathbf{~ m}$ & $\mathbf{0 , 9 0} \mathbf{~ m}$ & $\mathbf{1 , 1 0} \mathbf{~ m}$ & $\mathbf{1 , 3 0} \mathbf{m}$ & $\mathbf{E x t}$ & $\mathbf{1 , 5 0} \mathbf{~}$ & Trad & Alter & $\mathbf{M} / \mathbf{M}$ \\
\hline Base & 1,0 & 0,31 & 0,34 & 0,44 & 0,39 & 0,09 & 0,41 & 0,53 & 0,40 & 0,43 \\
\hline $0,70 \mathrm{~m}$ & & 1,0 & 0,61 & 0,66 & 0,54 & 0,34 & 0,69 & 0,71 & 0,64 & 0,67 \\
\hline $0,90 \mathrm{~m}$ & & & 1,0 & 0,79 & 0,56 & 0,38 & 0,72 & 0,72 & 0,74 & 0,73 \\
\hline $1,10 \mathrm{~m}$ & & & & 1,0 & 0,63 & 0,41 & 0,83 & 0,77 & 0,80 & 0,82 \\
\hline $1,30 \mathrm{~m}$ & & & & & 1,0 & 0,69 & 0,72 & 0,67 & 0,59 & 0,70 \\
\hline Ext & & & & & & 1,0 & 0,55 & 0,47 & 0,36 & 0,49 \\
\hline $1,50 \mathrm{~m}$ & & & & & & & 1,0 & 0,77 & 0,80 & 0,86 \\
\hline Trad & & & & & & & & 1,0 & 0,86 & 0,90 \\
\hline Alter & & & & & & & & & 1,0 & 0,93 \\
\hline M/M & & & & & & & & & & 1,0 \\
\hline
\end{tabular}

Ext $=$ mechanized extractor, with sample removed at 1,30 $\mathrm{m}(\mathrm{DBH})$. Trad, Alter and $\mathrm{M} / \mathrm{M}=$ traditional, alternative and sampling meter by meter, respectively.

It is possible to verify that the highest correlations were observed between the basic density estimated at $0,90 \mathrm{~m}$ and obtained at $1,10 \mathrm{~m}$ of soil height $(0,79)$ and $1,10 \mathrm{~m}$ with that obtained at $1,50 \mathrm{~m}$ height $(0,83)$ indicating that these points similarly estimate the basic density. Raymond (2002) found the highest correlation between the basic density estimated by the mechanized extractor and the mean basic density of the tree at 1,10 $\mathrm{m}$ for $E$. globulus and $0,7 \mathrm{~m}$ for $E$. nitens. These results reinforce the theory of decreasing density variation as the sampling height increases, at least up to the height values considered in this work.

The basic density estimated with the mechanized extractor method did not present a high correlation with the different basal sampling points of the tree trunks. However, at $1,30 \mathrm{~m}$ of soil height, the correlation was highest $(0,63)$, although a higher magnitude of correlation was expected. It is due to the non-proportionality of the basic density in the bagueta since it was removed considering the total diameter of the tree and not proportional to the areas of lower basic density in the radial direction, especially in the area near the tree pith.It can also be observed that the best correlation magnitudes between the estimates of wood density occurred at heights of 1,10 and 1,50 m soil, indicating that, for clones of E. grandis x E. urophylla, these are the heights 
that should be used to represent the whole tree better.

Raymond (2002) and Raymond and MacDonald (1998) also found the best correlations at 1,10 m and $1,50 \mathrm{~m}$ for E. globulus. Downes et al. (1997), using extractor samples, and volume-weighted disc samples as reference, suggest the removal of a single disc or a sample with extractor at $1,10 \mathrm{~m}$ for E. globulus from 5 to 7 years old $(\mathrm{r}=0,79)$. And at $0,70 \mathrm{~m}$ for E. nitens from 7 to 9 years $(\mathrm{r}=0,73)$ and at $1,30 \mathrm{~m}$ for E.regnans from 9 years $(\mathrm{r}=0,82)$. It is important to emphasize that these authors took into account not only the high correlation between the sampling height and the mean tree density but also the ease of reaching the point in the case of non-destructive sampling.

The evaluation of the wood properties performed at the height of $1,30 \mathrm{~m}$ from the ground is quite common, but there is little evidence that this point represents the value of the property in the trunk.

The correlations of $1,30 \mathrm{~m}$ of soil height, the most used point for taking a sample in the trunk, were $13 \%$, $26 \%$, and $15 \%$ lower than those obtained at $1,10 \mathrm{~m}$ of soil height, by the traditional method, and meters per meter, respectively. However, for $1,50 \mathrm{~m}$, correlations were lower by $13 \%, 26 \%$,and $19 \%$, for traditional, alternative and meter-to-meter sampling, respectively.

It was also verified that the correlations between the meter-by-meter methodology and the traditional sampling, and between meter per meter and the alternative sampling were very similar 0,90 and 0,93 respectively. However, for sampling with the same intensity ( 5 discs) and therefore presenting the same time and cost requirements, it can be concluded that the alternative sampling estimates the basic density of the trunk with higher accuracy.

\section{CONCLUSIONS}

For the determination of the mean basic density of the tree, the use of alternative sampling is suggested, since this method estimates the average core density of the trunk with values similar to those of the meter-by-meter sampling with the same number of samples from the traditional sampling.

Sampling in the form of baguettes using a mechanized extractor tended to underestimate the value of the basic density determined in the samples in wedge form due to the nonproportionality of the types of wood.

Among the three forms of sampling considered, the sampling of meterby meter, from $1,30 \mathrm{~m}$ in height, presented the highest values of correlation with the amplitude of the Resistograph and the penetration of the Pilodyn.

The sampling points of 1,10 $\mathrm{m}$ and 1,50 $\mathrm{m}$ of soil height showed, in general, the best correlations with the Resistograph amplitude and the penetration of the Pilodyn.

\section{REFERENCES}

Barría, C.; Sandoval, S.; Rojas, G. 2017. Uso del método de resistografía para la predicción de la densidad básica de la madera en árboles en pie de Pinus radiata. Maderas-Cienc Tecnol 19 (3): 349-362.

Barrichelo, L.E.G.; Brito, J.O.; Migliorani, A.J. 1983. Estudo da variação longitudinal da densidade básica de Eucalyptus spp. Silvicultura 8 (28): 726-731.

Couto, A.M.; Trugilho, P.F.; Neves, T.A.; Protassio, T.P.; Sa, V.A. 2013.Modeling of basic density of wood from Eucalyptus grandis and Eucalyptus urophylla using nondestructive methods. Cerne 19 (1): 27-34.

Downes, G.M.; Hudson, I.L.; Raymond, C.A.; Dean, G.H.; Michell, A.J.; Schimleck, R.; Evans, R.; Muneri, A. 1997. Sampling plantation eucalypts for wood and fiber properties. CSIRO: Melbourne, Victoria.

Fukatsu, E.;Tamura, A.; Takahashi M.; Fukuda, Y.; Nakada, R.; Kubota, M.; Kurinobu, S. 2011.Efficiency of the indirect selection and the evaluation of the genotype by environment interaction using Pilodyn for the genetic improvement of wood density in Cryptomeria japonica. J For Res 16 (2): 128-135.

Gouvêa, A.F.G.; Trugilho, P.F.; Gomide, J.L.; da Silva, J.R.M.; Andrade, C.R.; Alvez, I.C.N. 2011. Determinação da densidade básica da madeira de Eucalyptus por diferentes métodos não destrutivos. Revista 
Árvore 35 (2): 349-358.

Greaves, B.L.; Borralho, N.M.G.; Raymond, C.A.; Farrington, A. 1996. Use of a Pilodyn for the indirect selection of basic density in Eucalyptus nitens. Canadian Journal of Forest Research 26 (9):1643-1650.

Isik, F.; Li, B. 2003. Rapid assessment of wood density of live trees using the Resistograph ${ }^{\mathrm{TM}}$ for selection in tree improvement programs. Canadian Journal of Forest Research 33 (12): 2426-2435.

Lima, J.T.; Sartório, R.C.; Trugilho, P.F.; Cruz, C.R.; Vieira, R.S. 2007. Use of resistograph to estimate the specific gravity and the puncture resistance of Eucalyptus. Scientia Forestalis 75:85-93

Mackenzie, H.M.; Shelbourne, C.J.A.; Kimberley, M.O.; Mckinley, R.B.; Britton, R.A.J. 2003. Processing young plantation-grown Eucalyptus nitens for solid-wood products: 2. Predicting product quality from tree-, increment-core-, disc-, and 1-m billet properties. New Zealand Journal of Forestry Science 33 (1): 79113.

Nunes, A.C.P.; Santos, G.A.; Resende, M.D.V.; Silva, L.D.; Higa, A.;Assins, T.F. 2016. Estabelecimento de zonas de melhoramento para clones de eucalipto no Rio Grande do Sul, Brasil. Scientia Forestalis 44 (111): 563-574.

Omonte, M.; Valenzuela, L. 2011. Variación radial y longitudinal de la densidad básica en árboles de Eucalyptus regnans de 16 años. Maderas-Cienc Tecnol 13 (2): 211-224.

Pádua, F.A. 2009. Amostragem para avaliação da densidade básica da madeira de um hibrido de Eucalyptus grandisW. Hill ex Maiden x Eucalyptus urophylla S. T. Doutorado. Tese, Universidade Federal de Lavras, Lavras, Brasil. Available from <http://repositorio.ufla.br/handle/1/2937 > 531.

Raymond, C.A. 2002. Genetics of Eucalyptus wood properties. Annals of Forest Science 59 (5-6):525-

Raymond, C.A.; Macdonald, A.C. 1998. Where to shoot your Pilodyn ${ }^{\mathrm{TM}}$ : whiting tree variation in basic density in plantations Eucalyptus globulus and Eucalyptus nitens, Tasmania. New Forests 15 (3):205-221.

Raymond, C.A.; Muneri, A. 2001.Nondestructive sampling of Eucalyptus globulus and E.nitens for wood properties: I. basic density. Wood Science and Technology 35 (3):27-39.

Rinn, F.; Schweingruber, F.H.; Schar, E. 1996.Resistograph ${ }^{\mathrm{TM}}$ and x-ray density charts of wood: comparative evaluation of drill resistance profiles and $\mathrm{x}$-ray density charts of different wood species. Holzforschung 50 (4): 303-311.

Rosado, S.C.S.; Brune, A.; Oliveira, L.M. 1983. Evaluation of the wood basic density of standing trees. Revista Árvore 7 (2): 147-153.

Santos, I. D. 2008. Influência dos teores de lignina, holocelulose e extrativos na densidade básica, contração da madeira e nos rendimentos e densidade do carvão vegetal de cinco espécies lenhosas do cerrado. Mestrado. Dissertação, Universidade de Brasília, Brasília, Brasil. Available from $<$ http://repositorio.unb.br/ handle/10482/3594>

Sette Jr, C.R.; Oliveira, I.R.; Tomazello Filho, M.; Yamaji, F.M.; Laclau, J.P. 2012. Efeito da idade e posição de amostragem na densidade e características anatômicas da madeira de Eucalyptus grandis. Revista Arvore 36 (6): 1183-1190.

Wassenberg, M.; Chiu, HS.; Guo, W.; Spiecker, H. 2015. Analysis of wood density profiles of tree stems: incorporating vertical variations to optimize wood sampling strategies for density and biomass estimations. Trees 29 (2): 551-561.

Wei, X.; Borralho, N.M.G. 1997.Genetic Control of Wood Basic Density and Bark Thickness and Their Relationships with Growth Traits of Eucalyptus urophylla in South East China. Silvae Genetica 46 (4): 245 250 .

Zobel, B.J.; Van Buijtenen, J.P. 1989.Wood variation: its causes and control. Springer-Verlag: Berlin. 